\title{
Ocena wpływu hałasu szkolnego na wyniki testów centralnych funkcji słuchowych
}

\section{The evaluation of the influence of school noise on results of tests of central auditory processing}

Krzysztof Kochanek ${ }^{1,2}$, Lucyna Fajdek ${ }^{1}$, Adam Piłka²

${ }^{1}$ Uniwersytet Marii Curie-Skłodowskiej, Wydział Humanistyczny, Zakład Logopedii i Językoznawstwa Stosowanego, Lublin

${ }^{2}$ Instytut Fizjologii i Patologii Słuchu, Światowe Centrum Słuchu, Warszawa/Kajetany

Adres autora: Krzysztof Kochanek, Światowe Centrum Słuchu, ul. Mokra 17, Kajetany, 05-830 Nadarzyn, e-mail: k.kochanek@ifps.org.pl

\section{Streszczenie}

Cel: Ocena wpływu hałasu panującego podczas długich przerw międzylekcyjnych na wyniki testów centralnych funkcji słuchowych u dzieci.

Materiał i metody: Badaniami objęto grupę 19 uczniów w wieku 10 lat. Badania wykonywane były dwukrotnie - przed rozpoczęciem zajęć lekcyjnych oraz po kilku godzinach zajęć, tuż po zakończeniu długiej przerwy międzylekcyjnej (25 min). Badania prowadzono za pomocą testu słyszenia rozdzielnousznego - DDT, testu rozumienia mowy w szumie - aSPN oraz testu wykrywania przerw w szumie - GDT.

Wyniki i wnioski: Na podstawie wyników przeprowadzonych badań można stwierdzić, iż ekspozycja na hałas szkolny w trakcie przerw międzylekcyjnych nie wpływa znacząco na wyniki testów psychoakustycznych zastosowanych w pracy. Brak wpływu hałasu na wyniki testów centralnych funkcji słuchowych spowodowany był najprawdopodobniej zbyt krótkim czasem ekspozycji na hałas.

Słowa kluczowe: hałas w szkole • rozumienie mowy w szumie • zaburzenia przetwarzania słuchowego • wpływ hałasu

Abstract

Aim of the study: The purpose of this thesis is to evaluate the influence of the noise, that prevails during the long breaks at school, on the children's central auditory processing.

Material and methods: The study included a group of 19 students at the age of 10 years. The students were tested using the central auditory function tests. The tests were carried out before classes, after a few classes and during the long break ( $25 \mathrm{~min})$. Following psychoacoustic tests were used in this study: the Dichotic Digits Test (DDT), the Speech-in-Noise Test (aSPN), and the Gap Detection Test (GDT).

Results and conclusions: The research shows that the exposure to the school noise, that occurs during the school breaks, does not have any significant influence on the results of the psychoacoustic tests. The lack of the noise impact on the results of the central auditory function tests was probably caused by too short exposure to the noise.

Key words: noise at school $\bullet$ auditory processing disorders $\bullet$ speech in noise $\bullet$ noise effects

Wstęp

Hałas definiowany jest jako „niepożądane, nieprzyjemne, dokuczliwe lub szkodliwe drgania mechaniczne ośrodka sprężystego, działające za pośrednictwem powietrza na organ słuchu i inne elementy organizmu ludzkiego" [1].
Sposób, w jaki hałas oddziałuje na organizm ludzki, zależy zarówno od jego właściwości fizycznych (częstotliwość, natężenie, charakter, czas działania), jak i od indywidualnych predyspozycji danej osoby (wrażliwość osobnicza, wiek, płeć, indywidualne cechy budowy ucha) [2]. 
Wyniki licznych badań potwierdzają negatywny wpływ hałasu na zdrowie fizyczne i psychiczne człowieka. Wśród skutków długotrwałego narażenia na hałas wymienia się między innymi nadciśnienie, zaburzenia przemiany materii, zaburzenia w układzie nerwowym i naczyniowym, zmęczenie, zaburzenia snu [3]. Sułkowski [4] wskazuje, że długotrwałe natężenie na hałas powyżej $85 \mathrm{~dB}$ może powodować trwałe przesunięcie progu słyszenia, wywoływać bóle głowy i zaburzenia w funkcjonowaniu układów krążenia, nerwowego i równowagi, natomiast ekspozycja na hałas o natężeniu powyżej $130 \mathrm{~dB}$ może powodować uszkodzenie lub zniszczenie organów wewnętrznych (poprzez pobudzenie ich do drgań), wywołuje mdłości i zaburzenia równowagi, trwale uszkadza słuch, a także powoduje zaburzenia natury psychicznej (depresje, stany lękowe) [4].

Autorzy podkreślają, że nawet hałas o mniejszym natężeniu (poniżej $70 \mathrm{~dB}$ ), chociaż nie jest szkodliwy dla zdrowia, może powodować rozdrażnienie, zmęczenie, trudności z koncentracją czy trudności z zasypianiem [4].

Przeprowadzone przez Państwowy Zakład Higieny (PZH) badania hałasu w placówkach szkolnych wykazały, że warunki akustyczne $\mathrm{w}$ większości $\mathrm{z}$ nich nie odpowiadają krajowym normom $[5,6]$. Wysoki poziom hałasu w salach lekcyjnych, przekraczający wartości graniczne umożliwiające niezakłócony odbiór mowy, pochodzi zarówno ze źródeł zewnętrznych, jak i wewnętrznych. Według badań PZH aż 62\% szkół znajduje się w strefie oddziaływania hałasu ulicznego, często o natężeniu przekraczającym $55-65 \mathrm{~dB}, \mathrm{z}$ czego około 15\% znajduje się na obszarach, gdzie poziom hałasu przekracza $70 \mathrm{~dB}[7,8]$.

Głównym źródłem hałasu wewnątrz szkół jest różnorodna aktywność uczniów i nauczycieli, a także dźwięki produkowane przez urządzenia ogrzewania, klimatyzacji i wentylacji oraz dźwięki pochodzące $z$ korytarza i sąsiednich sal lekcyjnych. Badania PZH wskazują, że najgłośniejszymi pomieszczeniami w szkołach są korytarze. Podczas przerw międzylekcyjnych równoważne poziomy dźwięku A wahają się tam w granicach 66-98 dB (średnio $83 \mathrm{~dB}$ ), w czasie lekcji hałas jest nieco mniejszy (średnio $65 \mathrm{~dB}$ ) [7-9]. Wysokie równoważne poziomy dźwięku A występują również w salach lekcyjnych podczas zajęć i oscylują w granicach 53-75 dB [9-11].

Narażenie na hałas panujący w szkołach może powodować zmęczenie, rozdrażnienie oraz trudności w skupieniu uwagi, co z kolei może wpływać na obniżenie zdolności poznawczych, na procesy przetwarzania informacji, naukę czytania i pisania [12-18], pamięć $[13,15]$, umiejętność rozwiązywania zadań matematycznych [19,20], zdolności rozumienia mowy [21]. Negatywny wpływ hałasu na procesy uczenia się można zaobserwować szczególnie w grupach dzieci obarczonych dodatkowymi deficytami uwagi, specyficznymi trudnościami w czytaniu i pisaniu, niedosłuchem $[22,23]$.

Pod wpływem działania hałasu o średnim poziomie dźwięku A przekraczającym 75-80 dB (hałas na korytarzach szkolnych) może pojawić się objaw czasowego przesunięcia progu słyszenia (ang. Temporary Threshold Shift, TTS). Czasowe podwyższenie progu słyszenia u uczniów, ustępujące dopiero po upływie pewnego czasu, może również utrudniać rozumienie mowy i zakłócać proces nauki.

Nieliczne badania wskazują również na negatywny wpływ hałasu na ośrodkowe funkcje słuchowe. Badania na zwierzętach prowadzone przez Sun [24] i Gröschela [25] wykazały, że ekspozycja na hałas może powodować uszkodzenia kory słuchowej i hipokampu, a także zaburzać pracę neuronów ośrodkowego układu słuchowego. Dźwięki o dużym natężeniu mogą powodować deficyty uwagi słuchowej i koncentracji [26].

Badania wpływu hałasu na słuch, funkcje poznawcze i umiejętności szkolne dzieci prowadzone są w coraz większej liczbie ośrodków zarówno w Polsce, jak i na świecie. Do tej pory jednak nie opublikowano w Polsce wyników badań wpływu hałasu na ośrodkowe funkcje słuchowe. Dlatego w niniejszej pracy dokonano analizy wyników wybranych testów ośrodkowego przetwarzania słuchowego wykonanych przed ekspozycją i po ekspozycji na hałas panujący podczas przerw międzylekcyjnych.

\section{Materiał i metody}

Badaniami objęto 45 dzieci w wieku 10 lat, uczniów klasy IV szkoły podstawowej w Lublinie. U każdego dziecka wykonano badanie progowej audiometrii tonalnej dla częstotliwości 500, 1000, 2000, 4000 i 8000 Hz. Do dalszych badań zakwalifikowano dzieci, u których próg słyszenia na żadnej częstotliwości nie przekraczał $15 \mathrm{~dB}$ HL. Testy ośrodkowych funkcji słuchowych wykonano w grupie 19 dzieci.

Testy ośrodkowych funkcji słuchowych wykonano za pomocą programu APD (ang. Auditory Processing Disorder), opracowanego w Instytucie Fizjologii i Patologii Słuchu przez D. McPhersona, A. Senderskiego, H. Skarżyńskiego i K. Kochanka [27], zainstalowanego na Platformie Badań Zmysłów wyposażonej w słuchawki typu Sennheiser HDA 200. U każdej osoby wykonano trzy testy: rozdzielnouszny test cyfrowy DDT (ang. Dichotic Digit Test), test wykrywania przerw w szumie (ang. Gap Detection Test) oraz test rozumienia mowy w szumie aSPN (ang. Adaptive Speech in Noise).

Test DDT służy do oceny integracji słuchowej (badanie uwagi rozproszonej), separacji międzyusznej (badanie uwagi ukierunkowanej) oraz krótkotrwałej pamięci słuchowej. Polega on na podawaniu dwóch różnych par cyfr (od 1 do 10) jednocześnie do ucha lewego i prawego. Zadaniem osoby badanej jest zapamiętanie sekwencji 4 cyfr i powtórzenie jej w dowolnej kolejności. Bodźce prezentowane były $\mathrm{z}$ natężeniem $60 \mathrm{~dB}$. Wynikiem testu był odsetek prawidłowo rozpoznanych liczb w obojgu uszach.

Za pomocą testu GDT możliwa jest ocena rozdzielczości czasowej układu słuchowego (zdolności układu słuchowego do percepcji szybkich zmian w sygnałach akustycznych). W badaniu wykorzystano dwa rodzaje bodźców - standardowy (szum szerokopasmowy o intensywności $60 \mathrm{~dB}$ i czasie trwania $500 \mathrm{~ms}$ ) oraz zmienny (szum szerokopasmowy z „wcięciem” - przerwą w szumie). Test został przeprowadzony za pomocą procedury adaptacyjnej [27].. W badaniu w losowej kolejności prezentowano 
Tabela 1. Średnie wartości oraz odchylenie standardowe wyników testu DDT uzyskane w uchu prawym i lewym przed ekspozycją i po ekspozycji na hałas

Table 1. Mean values and standard deviation of DDT test results obtained before and after exposure to noise, in right and left ear

\begin{tabular}{ccccc}
\hline \multirow{2}{*}{ Wynik testu DDT } & \multicolumn{2}{c}{ Przed ekspozycją } & \multicolumn{2}{c}{ Po ekspozycji } \\
\cline { 2 - 5 } & $\overline{\mathbf{x}}[\%]$ & SD [\%] & $\overline{\mathbf{x}}$ [\%] & SD [\%] \\
\hline w uchu prawym & 76,8 & 15,2 & 79,3 & 14,5 \\
\hline w uchu lewym & 58,8 & 14,8 & 62,2 & 12,4 \\
\hline
\end{tabular}

Tabela 2. Średnie wartości oraz odchylenie standardowe wyników testu GDT uzyskane podczas badania przed ekspozycją i po ekspozycji na hałas szkolny

Table 2. Mean values and standard deviation of GDT test obtained during the examination before and after exposure to school noise

\begin{tabular}{cccc}
\hline \multicolumn{2}{c}{ Przed ekspozycją } & \multicolumn{2}{c}{ Po ekspozycji } \\
\hline$\overline{\mathbf{x}}[\mathrm{ms}]$ & SD [ms] & $\overline{\mathbf{x}}[\mathrm{ms}]$ & SD [ms] \\
\hline 3,1 & 2,0 & 2,7 & 0,7 \\
\hline
\end{tabular}

bodźce zmienne i standardowe. Zadaniem osoby badanej było naciśnięcie przycisku, kiedy usłyszy przerwę w szumie. Po uzyskaniu prawidłowej odpowiedzi (naciśnięcie przycisku w obecności bodźca zmiennego) długość przerwy w szumie zmniejszano o $2 \mathrm{~ms}$, natomiast po udzieleniu odpowiedzi nieprawidłowej wartość tę zwiększano o $2 \mathrm{~ms}$ (kiedy bodziec był zmienny, ale dziecko nie nacisnęło przycisku) lub o $4 \mathrm{~ms}$ (kiedy prezentowano bodziec standardowy, a dziecko nacisnęło na przycisk). Badanie kontynuowano do momentu, kiedy dziecko udzieliło 8 nieprawidłowych odpowiedzi. Wynikiem badania był średni próg wykrywania przerwy wyznaczony na podstawie 7 najniższych wartości długości przerw wykrytych przez słuchacza.

Test rozumienia mowy w szumie aSPN również wykonano za pomocą algorytmu adaptacyjnego. W badaniu tym jednosylabowe słowa prezentowano na tle sygnału maskującego typu „multitalker noise” o stałej intensywności $50 \mathrm{~dB}$. Zadaniem dziecka było powtórzenie usłyszanych słów. Po prawidłowym powtórzeniu słowa stosunek sygnału do szumu zmniejszano o $2 \mathrm{~dB}$, natomiast po udzieleniu nieprawidłowej odpowiedzi zwiększano o $2 \mathrm{~dB}$. Średni próg SNR (stosunek sygnału do szumu) wyznaczano na podstawie 4 najniższych wartości, przy których osoba badana udzieliła poprawnej odpowiedzi [27].

U każdego dziecka badania przeprowadzono dwukrotnie w ciągu dnia. Pierwszy pomiar wykonywano przed rozpoczęciem lekcji lub w trakcie pierwszej godziny lekcyjnej. Drugie badanie przeprowadzano w trakcie lekcji, tuż po zakończeniu długiej przerwy międzylekcyjnej (25 min). W obu badaniach testy wykonywano w tej samej kolejności: aSPN, DDT, GDT.

Do analizy statystycznej wyników zastosowano nieparametryczny test U Manna-Whitneya, test kolejności par Wilcoxona oraz test t-studenta dla prób zależnych w zależności
Tabela 3. Średnie wartości, odchylenia standardowe wartości SNR w teście aSPN przy stymulacji obuusznej przed narażeniem i po narażeniu na hałas szkolny

Table 3. Means and standard deviation of the SNR values in the aSPN test in binaural stimulation before and after exposure to school noise

\begin{tabular}{cccc}
\hline \multicolumn{2}{c}{ Przed ekspozycją } & \multicolumn{2}{c}{ Po ekspozycji } \\
\hline$\overline{\mathbf{x}}[\mathrm{dB}]$ & SD [dB] & $\overline{\mathbf{x}}[\mathrm{dB}]$ & SD [dB] \\
\hline$-0,85$ & 2,04 & $-1,23$ & 1,58 \\
\hline
\end{tabular}

od wyników analizy rozkładu. W badaniach przyjęto $\mathrm{p}<0,05$, jako wartość poziomu ufności.

\section{Wyniki}

Wyniki badań testu DDT dla ucha prawego i lewego przestawiono w tabeli 1. Zaobserwowano, podobnie jak w pracach innych autorów, że zarówno dla pomiaru pierwszego - przed przerwą obiadową, jak i podczas badania drugiego - wykonanego po przerwie wartości odsetka prawidłowo rozpoznanych cyfr $\mathrm{w}$ uchu prawym były istotnie większe niż w uchu lewym $(\mathrm{p}<0,001)[30,31]$. W uchu prawym nie stwierdzono istotnej statystycznie różnicy pomiędzy wynikami uzyskanymi w pierwszym i w drugim badaniu, natomiast w uchu lewym zaobserwowano, że odsetek prawidłowo rozpoznanych liczb $\mathrm{w}$ drugim badaniu był istotnie statystycznie większy $\mathrm{w}$ porównaniu $\mathrm{z}$ badaniem pierwszym $(\mathrm{p}<0,05)$. Zwraca uwagę mniejsza wartość odchylenia standardowego uzyskana podczas drugiego badania oraz uzyskanie nieznacznie większych wartości zarówno w prawym, jak i w lewym uchu podczas drugiego badania.

Przedstawione w tabeli 2 średnie wartości wykrytych przerw w szumie w badanej grupie w teście GDT były wyższe, gdy badanie wykonano podczas pierwszego pomiaru. Również wartość odchylenia standardowego podczas pierwszego pomiaru była blisko trzykrotnie większa. Analizy statystyczne nie wykazały, aby obserwowane zmniejszenie wielkości przerwy w szumie było istotne statystycznie $(\mathrm{p}>0,05)$.

Średni próg SNR w teście aSPN przed ekspozycją na hałas szkolny był nieco wyższy niż po ekspozycji, jednak analiza statystyczna nie wykazała istotnych różnic pomiędzy wynikami uzyskanymi podczas obu pomiarów ( $\mathrm{p}>0,05)$. W badaniu po ekspozycji na hałas zaobserwowano również mniejsze odchylenie standardowe w porównaniu $\mathrm{z}$ badaniem pierwszym (tabela 3 ). 


\section{Dyskusja}

Wybór testów w niniejszej pracy podyktowany był faktem, iż są one jednymi z najczęściej stosowanych testów w diagnostyce zaburzeń przetwarzania słuchowego oraz w badaniach przesiewowych. Za ich pomocą możliwa jest ocena integracji obuusznej, rozdzielczości czasowej układu słuchowego i umiejętności rozumienia mowy w szumie.

Prace innych autorów donoszą o niekorzystnym wpływie warunków panujących podczas lekcji, przerw międzylekcyjnych, obecności hałasu ulicznego na osiągnięcia szkolne uczniów oraz ich samopoczucie $[9,28]$, a także na procesy uczenia się, zapamiętywania i rozumienia mowy [21]. Liczne badania wykazały także, że zmęczenie i rozdrażnienie spowodowane hałasem mogą wpływać na wykonywanie zadań wymagających zaangażowania umiejętności językowych, pamięci oraz wymagających dużego skupienia [19,29,16,17,18]. Moch-Sibony [26] wykazał, że dźwięki o dużym natężeniu mogą powodować deficyt uwagi słuchowej i koncentracji.

Wpływ hałasu na centralne procesy przetwarzania słuchowego jest stosunkowo nowym obszarem badań. Testy przeprowadzane na zwierzętach wykazały, że narażenie na hałas w okresie dorastania może powodować opóźnienie w dojrzewaniu kory słuchowej, które może być związane z deficytami przetwarzania informacji czasowych w układzie słuchowym [34]. Badania Sun [24] i Gröschela [25] wykazały, iż ekspozycja na hałas może prowadzić do uszkodzenia kory słuchowej i hipokampu oraz powodować zaburzenia w pracy neuronów centralnej części układu słuchowego. Wyniki te, pomimo braku potwierdzenia w badaniach u ludzi, wskazują, że negatywne skutki hałasu można obserwować nie tylko w strukturach ucha wewnętrznego, lecz także w wyższych piętrach drogi słuchowej.

Na podstawie przeprowadzonych w niniejszej pracy badań nie wykazano wpływu kilkudziesięciominutowej ekspozycji na hałas panujący na korytarzach w szkołach, podczas przerw międzylekcyjnych, na wyniki zastosowanych w pracy testów ośrodkowych funkcji słuchowych. Wykonane analizy statystycznie nie wykazały, aby uzyskane wartości poszczególnych testów dla kolejnych pomiarów różniły się istotnie statystycznie, jednak zaobserwowano, że średni próg uzyskany w drugim badaniu był lepszy niż w badaniu pierwszym. Być może wyniki tych testów uległyby zmianie w wyniku dłuższej ekspozycji na hałas o większym natężeniu lub gdyby testy te wykonywane były w niesprzyjających warunkach akustycznych, podobnych do tych panujących w klasie podczas lekcji.

W niniejszych badaniach występował efekt poprawy wyników drugiego badania, który mógł być związany z faktem, że podczas drugiego badania dziecko znało już jego zasady. Jest on szczególnie widoczny w przypadku testu GDT. Średni próg wykrywania przerwy w szumie w drugim badaniu był niższy niż w badaniu pierwszym. Zmniejszyło się również odchylenie standardowe. Podobnie w teście aSPN - próg SNR w pierwszym badaniu był większy niż w badaniu drugim.

W badaniu DDT wykazano, że odsetek prawidłowo rozpoznanych cyfr w uchu prawym jest znacznie wyższy niż w uchu lewym. Jest to zgodne z wynikami wcześniejszych badań, które wskazują na przewagę ucha prawego (ang. Right Ear Advantage, REA) w badaniu uwagi rozproszonej przy użyciu bodźców słownych [30,31].

Nieznaczna poprawa wyników testów podczas drugiego i kolejnych badań została wykazana w pracach innych autorów [32,33]. Wykazali oni, podobnie jak wyniki badań uzyskanych w niniejszej pracy, nieznaczny wzrost wartości kolejnych testów, jednak poprawa ta nie była istotna statystycznie.

Pomimo iż w niniejszej pracy nie wykazano wpływu hałasu obecnego szczególnie podczas przerw szkolnych na ośrodkowe funkcje słuchowe, należy czynić starania o poprawę warunków akustycznych panujących w szkołach. Podczas kolejnych badań nad wpływem hałasu w szkołach wydaje się zasadne zastosowanie innych testów umożliwiających ocenę subtelnych elementów złożonego procesu przetwarzania słuchowego w warunkach narażenia na hałas.

\section{Piśmiennictwo:}

1. Engel Z i wsp. Raport - zagrożenie hałasem i wibracjami w Polsce. Warszawa: Komitet Akustyki PAN; 1984.

2. Grzegorczyk J, Halama A, Onisk Z. Wpływ wibracji i hałasu na zdrowie człowieka. Warszawa: Wydawnictwo Ministerstwa Obrony Narodowej; 1982.

3. Kotus J. Ocena wpływu zagrożeń hałasowych na częstość występowania chorób słuchu z zastosowaniem środków teleinformatycznych. Gdańsk: Politechnika Gdańska, Wydział Elektroniki, Telekomunikacji i Informatyki; 2007.

4. Sułkowski WJ. wykład 26.11.2010.

5. Augustyńska D, Radosz J. Hałas w szkołach (1) - przegląd badań. Bezpieczeństwo Pracy, 2009; 9(456): 16-9.

6. Augustyńska D, Radosz J. Hałas w szkołach (2) - wpływ hałasu szkolnego na uczniów i nauczycieli oraz jego profilaktyka. Bezpieczeństwo Pracy, 2009; 10(457): 8-10.

7. Koszarny Z, Goryński P. Narażenie uczniów i nauczycieli na hałas w szkole. Rocznik PZH, 1990; 5-6.
8. Koszarny Z. Warunki akustyczne w budynkach szkolnych. Zagadnienia higieniczne środowiska szkolnego. Materiały z konferencji Ocena stanu sanitarno-higienicznego szkół. Problemy Higieny, 2000; 66.

9. Shield B, Dockrell J. Children's perceptions of their acoustic environment at school and at home. J Acoust Soc Am, 2004; 115: 2964-73.

10. Szłapa P, Bronder A, Pawlas K. Klimat akustyczny w szkole jako czynnik sprawczy niewydolności narządu mowy nauczycieli. W: Majewski J, red. Hałas - Profilaktyka - Zdrowie. Koszalin: Polskie Towarzystwo Higieniczne Oddział w Krakowie; 2004.

11. Boryczka M, Łazicka M. Środowisko szkolne ucznia. Zastosowania Ergonomii, 2005; 1-3.

12. Hetu R., Truchon-Gagnon C., Bilodeau S. Problems of noise in school settings: a review of literature and the results of an exploratory study. J Speech Lang Pathol Audiol, 1990; 14: 31-8.

13. Evans G, Lepore S. Nonauditory effects of noise on children: a critical review. Children's Environ, 1993; 10: 31-51. 
14. Green KB, Pasternack BS, Shore RE. Effects of aircraft noise on reading ability of school-age children. Archives of Environmental Health, 1982; 37: 24-31.

15. Shield B, Dockrell J. The effects of noise on children at school: a review. Building Acoustics, 2003; 10: 97-116.

16. Bronzaft A. The effect of a noise abatement program on reading ability. J Environ Psychol, 1981; 1: 215-22.

17. Maxwell L, Evans G. The effects of noise on pre-school children's pre-reading skills. J Environ Psychol, 2000; 20: 91-7.

18. Clark C, Martin R, van Kempen E, Alfred T, Head J, Davies H i wsp. Exposure-effect relations between aircraft and road traffic noise exposure at school and reading comprehension: the RANCH project. Am J Epidemiol, 2006; 163: 27-37.

19. Cohen S, Evans G, Krantz D, Stokols D, Kelly S. Aircraft noise and children: longitudinal and cross-sectional evidence on adaptation to noise and the effectiveness of noise abatement. J Person Soc Psychol, 1981; 40: 331-45.

20. Dockrell J, Shield B. Children's perceptions of their acoustic environment at school and at home. J Acoust Soc Am, 2004; 115: 2964-73.

21. Klatte M, Meis M, Sukowski H, Schick A. Effects of irrelevant speech and traffic noise on speech perception and cognitive performance in elementary school children. Noise Health, 2007; 9(36): 64-74.

22. Bradlow A, Krauss N, Hayes E. Speaking clearly for children with learning disabilities: sentence perception in noise. J Speech Lang Hear Res, 2003; 46: 80-97.

23. Nelson P, Soli S. Acoustical barriers to learning: children at risk in every classroom. Lang Speech Hear Schools, 2000; 31: 356-61.

24. Sun W, Zhang L, Lu J, Yang G, Laundrie E, Salvi R. Noise exposure induced enhancement of auditory cortex response and changes in gene expression. Neuroscience, 2008; 2: 374-80.
25. Gröschel M, Götze R, Ernst A, Basta D. Differential impact of temporary and permanent noise-induced hearing loss on neuronal cell density in the mouse central auditory pathway. J Neurotrauma, 2010; 27(8): 1499-507.

26. Moch-Sibony A. Study of the effects of noise on personality and certain psychomotor and intellectual aspects of children, after a prolonged exposure. Travail Humane, 1984; 47: 155-65.

27. Dajos K, Piłka A, Senderski A, Kochanek K, Skarżyński H. Wyniki testów ośrodkowych funkcji słuchowych u dzieci i młodzieży w wieku szkolnym. Otorynolaryngologia; praca w druku.

28. Shield B, Dockrell J. The effects of environmental and classroom noise on the academic attainments of primary school children. J Acoust Soc Am, 2008; 100: 133-44.

29. Haines M, Stansfeld S, Head J, Job R. Multi-level modelling of aircraft noise on performance tests in schools around Heathrow Airport London. J Epidemiol Commun Health, 2002; 56: $139-44$.

30. Moncrieff DW. Dichotic listening in children: Age-related changes in direction and magnitude of ear advantage. Brain and Cognition, 2011; 76: 316-22.

31. Asbojrnsen AE, Hughdal K. Attentional effects in dichotic listening. Brain and Language, 1995; 49: 189-201.

32. Wilson RH, Bell TS, Koslowski JA. Learning effects associated with repeated word-recognition measures. Rusing sentence materials. Journal of Rehabilitation Research and Development, 2003; 40(4): 329-36.

33. Simões MF, Ferreira I, Schochat E. Test and retest of auditory processing: reliability of the evaluation. Revista da Sociedade Brasileira de Fonoaudiologia, 2011; 16(1): 42-8.

34. Sun W, Tang L, Allmana BL. Environmental Noise affects auditory temporal processing development and NMDA-2B receptor expression in auditory cortex. Behav Brain Res., 2011; 218(1): 15-20. 